\title{
Value and growth - Rethinking basic concepts in Lockean liberalism
}

\author{
Jennifer L. Bailey* \& May Thorseth
}

${ }^{*}$ Norwegian University of Science and Technology, Department of Sociology and Political Science, jennifer.bailey@svt.ntnu.no, corresponding author

Norwegian University of Science and Technology, Department of Philosophy and Religious Studies, may.thorseth@ntnu.no

DOI: http://dx.doi.org/10.5324/eip.v11i1.1967

(cc) BY

This is an open access article distributed under the terms of the Creative Commons Attribution 4.0 International License, which permits unrestricted use, distribution, and reproduction in any medium, provided the original author and source are credited.

This article argues that protection of the environment requires reconsidering basic liberal ideas relating to value and growth. It selects a central thinker in the liberal tradition, John Locke, as a starting point. The article first shows how Locke's political writings at first glance might support a "possessive individualist" position that gives primacy to individuals and their rights to property in a way that blocks governmental action to protect the environment, much as some modern versions of liberalism and libertarianism maintain. However, there are other aspects of Locke's writings that undermine this position. In particular, a reconsideration of his views on private property in combination with his views on the harm principle, the common good, and future generations can support the position that an individual's right to exploit nature is indeed limited. These elements of Locke are strengthened considerably if Locke's view of nature is updated by reconsidering nature as composed of ecosystems and as providing ecosystem goods and services. That land should continue to produce abundantly is foundational to Locke, and the failure to protect the ecosystems that provide key services supporting this abundance harms both the property of others and the viability of society: preservation of these constitute a collective good that transcends the individual good. The protection of ecosystem services also works to protect the value of individual holdings as well as the value of land still held in common. Finally, Locke's writing supports the view that it is the role of government to act to protect the abundance of nature, even against the wishes of an individual property owner.

Keywords: Growth, John Locke, private property rights, ecosystem goods and services, liberalism, environmental politics, role of government, nature

\section{Introduction}

"Growth" is a word associated with vitality and progress; by contrast, "stagnation" or "contraction" is usually taken to be a sign of fundamental trouble in an economy or society. At a different level, individuals aspire to growth, too - frequently in terms of increased consumption of material goods. At the same time, the message 
from ecologists is that human activities are pressing against key environmental thresholds. The concept and value of "growth" must then be reconsidered.

This article explores ways in which this can be done on a moral basis within the dominant liberal paradigm that regards growth, personal liberty and limited government as core values. It does this by examining the work of a key contributor to classical liberalism, John Locke. It finds within Locke much that suggests that human happiness requires ever-increasing consumption and that individuals have the right to exploit the Earth and its resources as they see fit. Together these notions define the core liberal value of liberty in Locke's writings, support modern capitalism and seem to block a reconsideration of the concept of growth. However, other strands of thought in Locke can serve to help reshape liberal ideas about growth in three ways: limits placed on individual rights with respect to private property by the harm principle; notions of the common good and the common inheritance of humankind; and the implied need to protect the productive powers of the land (a collective good). These arguments emerge more clearly and are strengthened when Locke's arguments are grafted onto a more modern understanding of nature, namely the concepts of the ecosystem and ecosystem goods and services. The limited task awarded to the state by Locke and classical liberalism, the protection of property, accordingly becomes the duty to protect property by protecting natural systems. Together, these aspects of Locke's thought support theoretical and practical limitations on the individual's use of natural systems. The rights of the individual are retained but are balanced both against the sum of individual goods and also against a higher, collective good. This collective good includes a broader need to support the underpinnings of social and economic institutions and (to some extent) the well-being of future generations. If these arguments hold, then the concept of growth need not require radical reconstruction, however much this might be desirable for other reasons.

The article first stakes out a position with respect to the need for limits on the use of the Earth's resources. It then explains the importance of a good argument in favor of limiting growth from within liberalism and why Locke was selected as the foundation upon which to build such an argument. Locke's views on private property, the pursuit of happiness and personal liberty are set out, and the difficulties these create with respect to an argument about limits are explored. The article then puts forward other aspects of Locke that can be used to build an argument in favor of limits and giving the state (government) a role in formulating and supporting limits on use. It next reconsiders Locke from an ecosystem perspective, arguing that changes in assumptions with respect to nature significantly change the outcome of Locke's analysis in a way that supports government action to protect the environment. This move entails recognizing that property rights can only be fully protected and the state can only carry out its injunction to protect private property (including but not limited to land) by protecting the productive power of ecosystems.

\section{Are there ecological limits to growth?}

The concept of "ecosystem" dominates current analyses of the environment. As defined in the Convention on Biological Diversity (Article 2), an ecosystem is "a dynamic complex of plant, animal and micro-organism communities and their non- 
living environment interacting as a functional unit." Inherent in the concept of the "system" are the ideas of structure, function and a notion of the dynamic equilibrium of the system. The ability of ecosystems to maintain or restore themselves when disturbed is known as their "resistance" (the ability to remain unchanged in the face of structure and function disturbance) or "resilience" (the ability to return to "normal" after such a disturbance) (Paterson, Defew and Jabour 2012: 26). If ecosystem structure and function are disturbed to the point that the existing system cannot be maintained or restored, then the ecosystem will change. This is described variously as "non-linear changes", "state changes" or "regime shift" (Stockholm Resilience Center 2015a; NOAA 2006). All of these terms refer to the long-term reorganization of the ecosystem, after some period of flux (Karunanithi, Cabezas, Frieden and Pawlowski 2008: 1).

While humans are widely understood to be a part of the Earth's many ecosystems, it is also the case that current levels of human use of the Earth's ecosystems (conceptualized here as Ehrlich and Holdren's I=PAT formula ${ }^{1}$ ) are widely understood to be putting increasing pressure on many of these. The Millennium Ecosystem Assessment (MEA) finds that "there is established but incomplete evidence that changes being made in ecosystems (including accelerating, abrupt, and potential irreversible changes) [. . .] have important consequences for human well-being" (MEA 2005: 1). Such consequences include: "disease emergence, abrupt alterations in water quality, the creation of 'dead zones' in coastal waters, the collapse of fisheries, and shifts in regional climate" (MEA 2005: 1). The Planetary Boundaries Group (PBG) based at the Stockholm Resilience Center has identified nine planetary "boundaries" or thresholds for the functioning of key Earth System processes,

within which we expect that humanity can operate safely. Transgressing one or more planetary boundaries may be deleterious or even catastrophic due to the risk of crossing thresholds that will trigger non-linear, abrupt environmental change within continental- to planetary-scale systems (Rockström, Steffen, Noone, Persson, Chapin, Lamkbin . . Foley 2009). ${ }^{2}$

The PBG estimates that humanity has already transgressed three of these boundaries: those relating to climate change, the rate of biodiversity loss and the global nitrogen cycle. Similarly, the latest report issued by the Intergovernmental Panel on Climate Change (IPCC) finds that "[h]uman influence on the climate system is clear" and that "[r]ecent climate changes have had widespread impacts on human and natural systems" (IPCC 2014: 2). It concludes that it is "extremely likely" that anthropogenic greenhouse gas emissions "driven by economic and population growth" have been the dominant cause of the warming observed since the mid-20th century (IPCC 2014: 4). In addition, the IPCC report concludes that changes in climate have already had widespread impact on natural and human systems; continued emissions of greenhouse gases will "increase the likelihood of severe, pervasive and irreversible impacts for people and ecosystems" (IPCC 2014: $6)$.

A persistent and vocal group disputes the validity of the global warming models ${ }^{3}$ or other warnings about the current fragility of ecosystems (Lomborg 2001; Shani and Arad 2014; Inhofe 2006; Clark and others 2006; Weisenthal 2009). Denying the idea of absolute limits is in part a question of ideational and possibly psychological 
disposition (Dryzek 2005). ${ }^{4}$ Others detect the operation of a "counter-social movement" backed by US conservative think tanks (Jacques 2009). In addition, it is not yet clear exactly what the limits on ecosystems are or how quickly we are reaching them; reasonable and capable researchers may disagree about whether and how environmental limits are being reached.

The position taken here, however, is that the preponderance of evidence today suggests that there are limits on use of ecosystems if they are to be maintained in a state around which modern society has been built (see also NASA 2015). It is a broadly accepted international norm that, faced with a situation of scientific uncertainty and high risk with respect to consequences, the "precautionary principle" be followed. ${ }^{5}$ This means that the burden of proof that an action will not cause harm shifts to those taking the action. Given the current state of knowledge about the Earth's ecosystems, we are compelled to act as if such limits do exist. Note too, that the principle of prevention is a "cardinal concept" of both human rights and environmental protection (Cullet 1995: 34). We are accordingly obligated to find a way to deal with the need for limits on the use of the Earth.

\section{The importance of a (liberal) argument for limits to growth}

Four reasons point to the need for a good argument grounded in political liberalism, for the purpose of establishing limits on the use of the Earth's resources. First, many modern countries are liberal democracies. The ideal that rational argument matters remains a part of the legitimacy of such political systems, even if the hopes once invested in the belief that the best argument will eventually persuade have faded. A principle that establishes limits on human action may help move populations to accept new conceptualizations of vitality that do not depend on an ever greater use of the Earth's resources. Second, however flawed these democracies may be, public opinion still carries some significance within them; that is, we can hold out hope that changing attitudes may result in actual change. Third, if we wish to preserve the idea of human agency we must invest in arguments that will help individuals make morally defensible choices.

Fourth, the literature on social movements and the "framing" of their causes suggests that arguments that draw upon existing cultural elements are most successful (Williams 2004; Snow, Rochford, Worden and Bendor1986; Pellow 1999). The dominance of liberal political philosophy in some key industrial countries of the modern world suggests that a liberal-based argument would be highly useful. In addition, liberalism is strongly linked both theoretically and historically with capitalism (although these are by no means identical), and capitalism has far greater influence than political liberalism: in both, a discussion of the role of the state and rights of the individual must be addressed in pursuit of good environmental policy. Successful arguments with respect to the one can have clear relevance to the other (more on this relationship below). Arguments from within liberalism and compatible with capitalism could be more successful in some key contexts than more radical arguments about the collective good or investing rights in non-humans such as animals, ecosystems or "nature".

Finally, this article speaks to the frequent claim that liberalism, including the Lockean variant, is particularly pernicious to the environment because it both encourages limitless growth and cultivates self-interest to the point that a collective 
good is neither recognized nor cultivated (Liebell 2011, p. 211; Wissenburg 2005, 180). It accordingly joins the recent work that reassesses both liberalism and Locke with respect to their potential to support an environmentalist position (see for example Trachtenberg 2014; Haddad 2003; Breakey 2014; Wissenburg 2005). ${ }^{6}$

\section{Looking at Locke}

John Locke (1632 - 1704) is widely recognized as a core founding father of classical liberalism, and his work remains broadly influential today. While classical liberalism has evolved over the years into more modern versions, including what Heywood (2012) has quite rightly called "market fundamentalism" (neo-liberalism) and libertarianism, classical liberalism remains at the core of the liberal tradition. Liberalism, in turn, has been frequently charged with supporting an approach to politics and economics (i.e. capitalism, really) that is highly prejudicial to the environment (as discussed, for example, in Wissenburg 2005).

The significance of the liberal tradition is reinforced by Locke's importance in the United States (Adler 2005; Hartz 1955; Wills 1999), as a country struggling to find the right balance between rights of individuals (especially with respect to property) and the role of government with respect to environmental and other issues. $^{7}$ While the extent to which Locke's writings directly influenced the US "founding fathers" is debated (see the extensive discussion in Simmons 1993: 101, fn 3 and Dunn 1969: 6-8, especially fn 3), Liebell (2011: 211) notes that modern US libertarians often use Locke's writings "to protect private property from environmental regulations and from government intervention through eminent domain"; Haddad (2003) points to the use of Locke, especially by rural US movements that seek to restrict the power of government with respect to environmental regulation (see also Meyer 2009). Jacques (2009) shows the importance of US conservative think tanks in arguing against the reality of climate change; these are often champions of what they suppose to be a Lockean version of liberalism. Robert Nozick (1974) is often cited as a key theorist supporting a strong view of private property in this context (Varden 2012), as are Milton Friedman, Leo Strauss and Richard Epstein (Vaughn 1980; Meyer 2009).

It is particularly useful to find an argument within the Lockean canon because Locke predates Marx. Politically, any argument for collectivist-based, or groupbased rights tends to evoke comparisons with what is frequently seen as a discredited ideology. In Locke, this article contends, an argument is made in favor of a collective good that cannot be said to derive from Marxism and which preserves individual rights.

Locke's work also predates much modern work that builds a case for protection of the environment on the premise that animals, or the environment itself, have rights. Classical liberalism is not just individualist in its focus, it is focused on the human individual. That is to say, it is unapologetically anthropocentric. While for some its anthropocentric character automatically disqualifies liberalism (and accordingly, Locke) as an acceptable or even as a possible avenue towards a truly sustainable society, it is argued here that an approach embodying an anthropocentric character is most likely to be politically successful. In a liberal context, such an approach may be stronger (that is, more generally persuasive) than 
an argument that builds on a repudiation of or an uncomfortable extension of liberal cornerstones. ${ }^{8}$

\section{Locke and possessive individualism}

The individual's right to private property is understood to be a cornerstone of the liberal tradition (Heywood 2012; Wissenburg 2005), and Locke's views on private property are often singled out as particularly important (Haddad 2003; Ince 2011: 29; Liebell 2011: 211; Trachtenberg 2014: 99). One reading of Locke privileges the rights of the individual with respect to property over the right of the state (government) to "interfere" with the individual's use of his or her property; this view unites left-wing critics of Locke such as C. B. Macpherson with libertarian supporters of expansive rights for individuals against the state or any notion of a collective good that transcends the sum of individual goods. This reading of Locke was most famously put forward by C. B. Macpherson $(1962,1973)$ as "possessive individualism". There is much in Locke that supports this interpretation. However, much contemporary scholarship disputes this reading of Locke (see for example Varden 2012; Breakly 2014; Trachtenberg 2014; Sigmund 2005; Simmons 1993 Waldron 2002). The "possessive individualist" position is laid out here but reconsidered in the next section.

Two aspects of property need to be considered in this context. First, does Locke place any limits on an individual's possession of property and, by extension, consumption of the products of nature? Second, does Locke place any limits on what individuals may do with the property they possess? Because the concept of property as discussed by Locke is intimately linked to the land that is the ultimate source of wealth, it provides a clear avenue towards the discussion of the protection of nature and natural systems themselves.

Summarizing these views is complicated, because Locke's view of the state of nature is a mixture of abstract construct and assumptions about nature and the world around him. He draws from the Bible, ancient history and his understanding of what was to be found in "America", in addition to his understanding of his contemporary English (and historical) society (Miller 1980; Hindess 2007; Waldron 1979; Dunn 1969; Simmons 1993). In addition, Locke's views are ambiguous, spread over several works, and they developed over time. They are complex enough to yield plausible (at least to some) readings of Locke as the extreme individualist (Nozick 1974) and Locke as the extreme collectivist (Kendall 1965). Simmons (1993: 13-31) argues convincingly that there is no single "state of nature" in Locke (the original position is just one of several possible situations in which an individual could exist in a state of nature with respect to others). The following account of Locke's position is a fairly standard one, although each point presented could be debated and frequently has been.

Locke's arguments about property pull in different directions. Locke clearly introduces the idea of limits to any single individual's possession of the Earth as his first position. First, he argues that humans in a state of nature (before the establishment of political society) were free to take as much from the Earth as they wanted because there were so few people; after they took what they wanted, there was still plenty for others to take as much as they wanted. Adam's unlimited sating of his appetites caused no harm to others $\left(2^{\text {nd }} \mathrm{T}, \mathrm{Ch} . \mathrm{V}, \S 33\right)^{9}$. But the individual 
was never unconditionally free to take unlimited amounts: there should be "enough and as good" left to others ( $2^{\text {nd }} \mathrm{T}, \mathrm{Ch} \mathrm{V}, \$ 33$; Liebell 2011). ${ }^{10}$ Given that Locke views all individuals as being of equal moral worth in the state of nature, this line of argument suggests that once the remainder was no longer "enough and as good", there would be limits on what Adam (or anybody else) could take.

Second, Locke holds that a person may only take as much as he can actually use $\left(2^{\text {nd }} \mathrm{T}, \mathrm{Ch} . \mathrm{V}, \S 31\right.$ ), or as he puts it, “[a]s much as anyone can make use of to any advantage of life before it spoils [. . .] Whatever is beyond this is more than his share, and belongs to others." Individuals have no right to pile up resources that will spoil before they are used, and there is little point in doing so, either.

Third, Locke's notion of how property is created places potential limits on what an individual may possess. Starting from the proposition that one indisputably owns one's own body and thus one's own labor, he argues that by transforming products of nature that were originally held in common, an individual comes to own them $\left(2^{\text {nd }} \mathrm{T}, \mathrm{Ch} . \mathrm{V}, \S 27\right)$. Ownership derives from the creation of something by "mixing labor with it". Given that an individual can only do so much in a single lifetime, this also implies limits.

However, Locke then introduces elements that seem to remove limits from what any individual has the right to possess, and by extension, what individuals can collectively use with respect to the Earth.

First, he writes that there is a difference in the productive capacity of unimproved nature compared to improved nature. Farmed land, he observes, produces more abundance than does a wild, unfarmed tract - by a factor of 10,100 , 1000 or more - as technology, skill and commerce allow and make realizable $\left(2^{\text {nd }} \mathrm{T}\right.$, Ch. V, $\$ 37,40,43,48$; Reno 2009: 656). Locke stresses the importance of worked land to the point that he writes that "land that is left wholly to nature, that hath no improvement of pasturage, tillage, or planting, is called, as indeed it is, waste; and we shall find the benefit of it amount to little more than nothing" $\left(2^{\text {nd }} \mathrm{T}, \mathrm{Ch} . \mathrm{V}\right.$, $\$ 42)$. The increase in the productive power of the Earth means that the absolute limits imposed by the Earth - here represented by the amount of land available - are transcended. While the amount of land might be limited (although Locke thought at the time that there was still plenty of this to go around, in America if not in England - as in $2^{\text {nd }} \mathrm{T}$., Ch. V, $₫ 45$ ), the amount of life-sustaining abundance is not (Miller 1980). Owning a great deal of land (or other natural resource) then does not necessarily harm others, even should there be actually little "as good as" (and certainly not "enough") left for them, for they can share in the abundance produced by the land without owning it directly. Ince (2011) goes so far as to argue that for Locke, subjugation of the land and the generation and accumulation of value is both highly moral and necessary for human progress.

In addition, land is highly productive when farmed by those who know what they are doing, a skill not equally distributed amongst the population ("God gave it [the world] to the industrious and rational” $\left.2^{\text {nd }} \mathrm{T}, \mathrm{Ch} . \mathrm{V}, \$ 34\right)$. A thriving farm also requires labor, which will allow those without land, and perhaps a different skill set, to partake in the riches that cultivated land produces. Those with less or no land are still better off than they would be in the state of nature, even if they do not share absolutely equally in land or even in the abundance it produces.

Second, Locke introduces money. Because money does not spoil, there is no absolute limit on how much of it one might possess $\left(2^{\text {nd }} \mathrm{T}, \mathrm{Ch} .5, \S 46\right)$. This to some 
extent liberates wealth from land, removing it from any discussion on limits. Note that for Locke, the invention of money predates the invention of political community, as does ownership. The political community-and government-is instituted to protect property (defined by Locke as life, liberty and estate $\left[2^{\text {nd }} \mathrm{T}\right.$. Ch. VII $₫ 87])$.

Third, Miller (1980) points out that Locke's labor theory of ownership apparently operates indirectly. That is, to establish ownership it is not necessary for individuals to mix their own labor with nature. Ownership can be established via the labor of servants that the estate owner hires. Servants, owning their own labor, in essence sell that labor to the owner who then owns the fruits of the servants' labor. This again works to remove limitations on the amount of wealth that an owner of an estate might accumulate.

If we agree that land ownership (and the inequality that this implies) is acceptable in Locke's account, to what degree is ownership inviolable? To what degree, if at all, must the individual give precedence to some version of the common good with which he may potentially not agree? There is indisputably a tension in Locke between the right of the individual with respect to private property and the moral requirement to act within the law of nature. The trick has always been to understand what Locke thinks the balance between these two positions is. In Macpherson's possessive individualist version of Locke, the balance shifts in favor of the right of the individual via the construction of a strong (or full) version of private property ownership (Otsuka 1998: 66) ${ }^{11}$ :

(1) Man, the individual, is seen as absolute natural proprietor of his own capacities, owing nothing to society for them. Man's essence is freedom to use his capacities in search of satisfactions. This freedom is limited properly only by some principle of utility or utilitarian natural law which forbids harming others. Freedom therefore is restricted to and comes to be identified with, dominion over things, not domination over men. The clearest form of domination over things is the relation of ownership or possession. Freedom is therefore possession. Everyone is free, for everyone possesses at least his own capacities. (2) Society is seen, not (as it had been) as a system of relations of dominions and subordination between men and classes held together by reciprocal rights and duties, but as a lot of free equal individuals related to each other through their possessions, that is, related as owners of their own capacities and of what they have produced and accumulated by the use of their capacities. The relation of exchange (the market relation) is seen as the fundamental relation of society. Finally (3) political society is seen as a rational device for the protection of property, including capacities; even life and liberty are considered as possessions, rather than as a social right with correlative duties (Macpherson 1973 cited by Miller 1980, 262-3).

As Macpherson interprets Locke, then, property is strongly associated with the freedom of the individual, particularly since life and liberty are two of the three components of property (along with estate) [2nd T. Ch. VII $\$ 87]$ ). "Possessions" are as important as life and liberty, and become the means by which life and liberty are made actual. Locke's statements in the Second Treatise about the centrality of property and the right of the individual to dispose of it as he sees fit, seem to support MacPherson's reading, as Locke defines freedom as “... liberty to dispose, 
and order as he lists, his person, actions, possessions, and his whole property, within the allowance of those laws under which he lists, and therein not to be subject to the arbitrary will of another, but freely follows his own” $\left(2^{\text {nd }} \mathrm{T}\right.$., Ch. VI, §57). While MacPherson recognizes that Locke does have a notion about the limits imposed by natural law (and the cited passage from Locke also argues that acting within the bounds of (natural) law is required for the achievement of true freedom), MacPherson writes that "Locke's astonishing achievement was to base the property right on natural right and natural law, and then to remove all the natural law limits from the property right" (1962: 199). In this interpretation, then, Locke's understanding of property involves the almost unlimited right of the individual to acquire as much property as he likes and to do with this property what he likes.

Together, these principles impose very few limitations on how humans use nature, either collectively or individually. In addition, the purpose of government is to enforce property rights. This argument lies at the crux of the analyses of those who hold that Locke's view of private property is pernicious with respect to protecting the environment. From our perspective, two additional points that Locke purveys in the Second Treatise of Government and elsewhere compound this problem. First, as Schneewind (1994) summarizes Locke's view, "our main business is to live well and prepare ourselves for the afterlife". In general, scholars today take Locke's personal faith to be a far more important component of his work than previously acknowledged (Sigmund 2005; Ince 2011). But much in Locke revolves around living well ${ }^{12}$ and very little concerns self-abnegation, e.g. in connection with "prepar[ation] for the afterlife". On the contrary, Locke uses a proto-utilitarian approach to measure the appropriateness of actions: the amount of pleasure and avoidance of pain those actions produce in the individual (Schneewind 1994; Locke [1689]). ${ }^{13}$

Related to this, Reno (2009) argues convincingly that Locke understands humans to be driven first and foremost by a fundamental sense of "uneasiness of the mind for the lack of some absent good," which is in turn the product of "all bodily pain of whatever kind, and all disquiet of the mind" (ECHU \$31). While people can want many types of goods, clearly material goods are included here. Human uneasiness is essentially insatiable and tends to crowd out human concern for some more abstract form of "good" (ECHU $₫ 41$ ). Rather than establish any limits to these via a moral code, Locke accepts that promoting individual happiness so configured constitutes the aim of government. Government at best channels human desires; it does not diminish or constrain them. Because human desires cannot be sated, they imply continued growth, and accommodating this becomes the end of political society and of government. It is in fact the multiplication of need beyond the basic level that is the engine of commerce, which in turn provides the impetus to unleash the productive power of land - making life far more agreeable than it would be in a primitive state.

\section{Limiting Locke}

Macpherson's possessive individualism reading of Locke is one persuasive interpretation of his complex body of writings, but it is hardly an uncontested one (Simmons 1993: 88-90; Waldron 2002: 170-1). Breakly (2014: 63) pronounces it "wrong, root and branch", arguing that it is simply an incorrect reading. Varden 
(2012) argues that the possessive individualist interpretation of Locke violates Locke's fundamental assumption that individuals are inherently equal, and in so doing destroys the foundation for Locke's position that individuals have the rightful authority to defend their possessions against all comers. Indeed, there seems to be fundamental tension in Locke, and perhaps in liberalism as a whole, between the ideals of equality and of private property (Wissenburg 2005: 182). Even so, a reading of Locke does not turn up support for a redistribution of property held in civil society in order to achieve absolute equality, and the text does apparently recognize and accept social divisions by which some hold land and others work on it. As Locke states in Chapter V, On Property:

[...] it is plain, that men have agreed to a disproportionate and unequal possession of the earth, they have, by a tacit and voluntary consent, found out, a way how man may fairly possess more land than he himself can use the product of, by receiving in exchange for the overplus of gold and silver, which may be hoarded up without injury to anyone; these metals not spoiling or decaying in the hands of the possessor ( $\$ 50$; see also $\$ 45$ ).

Assigning to the state the role of protecting private property becomes in this context an acceptance of inequality; the endless redistribution of land to meet requirements for equality would not be feasible and would discourage the individual from investing labor in the land. In addition, continual redistribution of land would also be disruptive enough that the productivity of the land would be diminished.

However, the reading of Locke that finds support for such social divisions must also accept that the property owner retains an obligation to preserve mankind as well as him- or herself, a frequent injunction throughout the Second Treatise (Goldwin 1976). This suggests that wages due to laborers should be figured with this in mind. In this way, the strong obligation in Locke to consider the welfare of others can apparently be discharged, although Locke does not explicitly make this argument. At the same time, it is clear that acceptance of ownership inequality must also be linked to the continued production of a healthy surplus that can then be available for sharing. The importance Locke gives to the increased abundance produced by improved land - the developed society of England, so vastly different from that of the American Indian, provides the justification for enclosing land makes preservation of the productive capacity of the land an unrecognized but fundamental condition for the right of anyone to enclose land. Trachtenberg (2014: 107) argues that Locke allows for enclosure and use of land but stops short of giving people absolute ownership of the land: the individual's right is better described as usufructuary. Although it can be argued as to whether Locke unambiguously supports this characterization, ${ }^{14}$ Trachtenberg does nicely capture the fundamental need to maintain land in a condition to remain highly productive. To put this into language explained further on in this essay, the ability of the land to continue to deliver essential goods and services is an underlying assumption in Locke's view.

There are additional explicit and some implicit ideas within Locke about the existence of a collective good beyond the individual, but these must be stretched a bit to do the required work.

First, there are hints that Locke believes in a society that exists beyond the individual and which is not just a sum of the activity of atomistic individuals. Locke presupposes the existence of many social conventions before the institution of a 
political society, for example money. Money, made of matter that is of little direct use to most people, only has the value that is commonly assigned to it ( $2^{\text {nd }} \mathrm{T}$., $\mathrm{Ch}$. V, $\$$. 50). A commonly agreed upon value for money suggests the existence of a broad consensus, a concept that is difficult to reconcile with the notion of "society" as composed of a collection of asocial individuals, even if Locke argues that agreement on the value of money happens tacitly (that is, without an explicit compact). Locke also assumes the existence of language. An overtly constructivist sort of reasoning, in which the social dominates the individual, is conspicuously absent in Locke, ${ }^{15}$ and yet, money and language are generated in some fashion before the establishment of a political society.

Locke notes elsewhere in the Second Treatise that humans are essentially social animals, quoting the "judicious Hooker" when he writes that "we are naturally induced to seek communion and fellowship with others; this was the cause of men's uniting themselves at first in politic societies" ( $2^{\text {nd }}$ T., Ch. II, $\left.₫ 15\right)$. Liebell (2011: 221) argues that Locke's humans "possess an interest in the rest of mankind" as a part of their basic makeup. In the absence of government, they first look after themselves but then look to "the preservation of Mankind" (Locke $2^{\text {nd }} T$, Ch. $1 \S 6$ ). However, this is somewhat balanced out by the argument that looking to the good of others is a form of self-preservation $\left(2^{\text {nd }} \mathrm{T}, \mathrm{Ch} .1, \$ 6\right)$ and that people associate for a more pragmatic reason: "to furnish ourselves with competent store of things", that is, in order to live the kind of good life to which he assumes we all aspire $\left(2^{\text {nd }} T\right.$., Ch. II, $\$ 25)$. In section 101, Locke notes that "the inconveniences of that condition [the state of nature], and the love and want of society, ... brought any number of them together." 16 The want of society and the desire for "convenience" are usually coupled - which is to say that it is as much the desire to create a particular lifestyle that drives men together as it is need of interaction with other humans. As Reno (2009) points out, living in a society with the trade required to stimulate the production of the many goods that humans want makes people dependent upon each other. Again, while there are useful strands of thought here, they are fragile things, particularly since Locke seems to merge the idea of forming a "community" and a "society" with that of creating a "body politic," which presumably means the existence of a government (see for example $2^{\text {nd }}$ T., Ch. II, $\$$. 14; and Simmons' discussion of Locke's terminology at 1993: 4-5). This confuses the issue of the autonomy of the individual in a state of nature.

However, Locke explicitly describes three kinds of social relations that can serve as a source from which a collective good beyond the direct benefits to individuals might be derived. First, in both the First and Second Treatise on Government, Locke makes much of the equality of men in their origins. They are equal in their rights from God and in their essential natures (Ch. II, $\$ 4$ ). On the one hand, this can be read as supporting individual autonomy, since no individual is subject to another individual. On the other hand, Locke, again drawing upon Hooker with approval, argues that this very equality is "the foundation of that obligation to mutual love amongst men, on which he builds the duties they owe one another, and from whence he derives the great maxims of justice and charity" ( $2^{\text {nd }} \mathrm{T}$, Ch. II, §5).

Beyond relationships that stem from the need to protect property rights, Locke does explicitly note the existence of other genuinely human relationships, such as secondly, between husband and wife and thirdly, between parents and children. In this case, the bond between parents and children is of greatest interest, because it 
carries with it some obligation by the owner of property to care for others and to safeguard what they are to inherit. Locke notes in $1^{\text {st }}$ T., $\$ 88$ :

Men are not proprietors of what they have, merely for themselves; their children have a title to part of it, and have their kind of right joined with their parents in the possession, which comes to be wholly theirs, when death, having put an end to their parents use of it, hath taken them from their possessions; and this we call inheritance: men being by a like obligation bound to preserve what they have begotten as to preserve themselves, their issue come to have a right in the goods they are possessed of.

Concern for one's offspring is, according to Locke, an inherent characteristic of humankind ( $2^{\text {nd }}$ T., Ch. VI, $\left.\$ 60\right)$. This concern for the future lays the foundation for the obligation of current generations towards future generations. This is still a limited notion of intergenerational justice, however, because it applies primarily within families. However, it does suggest that the impact of individual action on potential future generations is relevant to Locke's deliberations and could be brought to apply to other aspects of this thought. It supports the idea that one generation should care for the land and its productive power, which it in essence holds in trust for successive generations.

In a related argument, Trachtenberg (2014: 106-107) argues that Locke does not establish the moral priority of any early generation: all generations are on an equal moral footing. Even if the proviso to leave "enough and as good as" does not necessarily mean that land must be divided equally among all comers - a proposition that is conceptually as well as practically difficult (Varden 2012) - there is no way around the idea that nature itself should be left to future generations in a state that is "enough and as good as" the state in which the previous generation found it.

Trachtenberg's position is strengthened by the notion of common ownership of the Earth to be found in Locke. Locke notes that "it is very clear that God [...] has given the earth to the children of men; given it to mankind in common" $\left(2^{\text {nd }} \mathrm{T}\right.$., Ch. $\mathrm{V}, \S .25)$. This, plus the many statements to the effect that man is equal in the state of nature, seems to be a powerful argument in favor of a common interest in preserving the Earth. However, Locke also argues that even so, individuals can make "several parts" of this into their own property, even "without any express compact of all the commoners" ( $2^{\text {nd }} \mathrm{T}$., Ch. V, $\left.\S .26\right)$. Locke thus does recognize some sort of common good, but as noted above, also writes strongly in support of the legitimacy of some individuals appropriating a part of the land and establishing exclusive use over it as society develops. This is in fact a precondition for societal development.

Before moving on from the notion of ownership, it is worth pausing to consider again how individuals establish private ownership over that which God gave to man in common: by mixing labor with land or another natural resource, either one's own or an agent's. This does imply, however, that an individual cannot own that with which he cannot mix his labor. One might mix one's labor with land, but it is harder to see that the ocean or atmosphere, for example, could be owned in this sense. Individuals might own the fish they remove from the seas but not the fish in the seas that remain at large. Much of the world, then, remains held in common by humankind, with each human thereby accorded equality with respect to it. 
The idea that God has created the world, and we - and all creation - thereby belong to Him takes us some way down the road to where we want to go. Locke is ambiguous here. On the one hand, as noted, Locke supports the idea of private property and that land and the so-called "inferior creatures" are to be at the disposal of humankind. But he does note limits on what humans may do to themselves and to others, and these could be extended to their property and life-giving sustenance:

[T] hough man in that state [of nature] have an uncontrollable liberty to dispose of his person or possessions, yet he has not liberty to destroy himself, or so much as any creature in his possession, but where some nobler use than its bare preservation calls for it ( 2 nd T., Ch. II $\$ 6$ ).

Even so, Locke makes no explicit injunction as to what has become known as "creation care" 17 , or the duty of humankind to be good stewards of the Earth as such; nor does he explicitly recognize that the Earth itself needs tending or protection in any way in order to remain productive.

A stronger statement is found in Locke's version of the harm principle: It does not address the Earth or nature per se, but does place limits on what one may do to fellow humans. The most famous passage of Locke's Second Treatise may be the following:

But though this [the state of nature] be a state of liberty, yet it is not a state of licence: [...] The state of nature has a law of nature to govern it which obliges every one: and reason, which is that law, teaches all mankind, who will but consult it, that being all equal and independent, no one ought to harm another in his life, health, liberty, or possessions: for men being all the workmanship of one omnipotent, and infinitely wise maker; all the servants of one sovereign master, sent into the world by his order, and about his business; they are his property, whose workmanship they are, made to last during his, and not one another's pleasure: and being furnished with like faculties, sharing all in one community of nature, there cannot be supposed any such subordination among us, that may authorize us to destroy one another, as if we were made for one another's uses, as the inferior ranks of creatures are for ours. Every one, as he is bound to preserve himself, and not to quit his station willfully, so by the like reason, when his own preservation comes not in competition, ought he as much as he can, to preserve the rest of mankind and may not, unless it be to do justice on an offender, take away, or impair the life or what tends to the preservation of the life, the liberty; health, limb or goods of another $\left(2^{\text {nd }}\right.$ T., Ch. II $₫ 6$, italics ours).

Here there is a solid foundation upon which to build. Instead of questioning Locke's argument in favor of the right of the individual to convert the land held in common to private property - which, despite the logical contradictions in Locke's argument that appropriating property leads to, it is difficult to do - the importance of private property can be embraced as the foundation for environmental regulation. First, the abundance produced by improved land is the foundation for much that is valued in society, and is a key justification for accepting private ownership of land itself. Protection of its productive capacity (from an ecosystem perspective) is thereby fundamental for preserving the value of a given individual's land. Second, the core 
value of property and the injunction that we may not harm others or their property become reasons for safeguarding the environment in general.

\section{A Role for Government}

Locke stresses throughout the Second Treatise that the function of government is to secure property, understood in both the narrow sense of possessions and in the larger sense of life, liberty and estate. Section 134 in Chapter XI of the Second Treatise is a typical example of how he expresses this: "The great end of men's entering into society, being the enjoyment of their properties in peace and safety". In the state of nature, all are equal and all accordingly have the right to punish violations of property. But the lack of disinterested judges lends an arbitrary nature to the punishment of wrongdoing. In addition, not all have the strength to enforce their own rulings, however judicious or arbitrary.

To avoid these inconveniences, which disorder men's properties in the state of nature, men unite into societies, that they may have the united strength of the whole society to secure and defend their properties, and may have standing rules to bound it, by which everyone may know what is his. To this end it is that men give up all their natural power to the society which they enter into, and the community put the legislative power into such hands as they think fit, with this trust, that they shall be governed by declared laws, or else their peace, quiet, and property will still be at the same uncertainty, as it was in the state of nature ( $2^{\text {nd }}$ T., Ch. XI, $\left.\$ 136\right)$.

Locke here establishes two things. First, he argues that the protection of property in both the narrow and broad senses of the term is the purpose of government, despite writing as if violations of property were mostly a question of someone taking what belongs to others. Second, he establishes that individuals might not always be aware of their own best interest. To the problem that individuals are not "disinterested judges" in questions relating to their own interests can be added the power of "uneasiness" that drives individual action and the individual's corresponding difficulty with pursuing an abstract good, as noted above. Sometimes, others must step in - hence the creation of a government.

As Locke moves on to establish the legitimacy of the imposition of a tax by a government, he recognizes that while property cannot be taken without consent, consent need not mean that every individual must give explicit approval on every occasion; a decision arrived at democratically will do. In deciding taxes, for example, Locke notes that a person should pay his share out of his estate, "but it still must be with his own consent, i.e., the consent of the majority giving it either by themselves, or their representatives chosen by them" $\left(2^{\text {nd }}\right.$ T, Ch. XI. $\left.\$ 140\right)$. Elsewhere ( $2^{\text {nd }} \mathrm{T}$., Ch. VI, $\$ 73$ ), Locke explicitly notes that there is always "annexed to the enjoyment of land, a submission to the government of the country, of which that land is a part." This line of reasoning supports the argument that government might act without the explicit consent of a landowner to impose some limitations on the use of land, if in so doing the government action protects the private property of others, e.g. from the harm done by another landowner.

A final point is that Locke recognizes the "strong desire for self-preservation" as a fundamental characteristic of man (i.e. as a characteristic God has "planted in him") 
$\left(1^{\text {st }} \mathrm{T} ., \S 86\right)$. This is not something that is given up, whether in the state of nature or in political society. If the self-preservation of some is threatened by the actions of others, even if those actions take place on private property, those threatened retain the right to act. In a political society, individuals delegate that job to the government.

\section{Changing Locke's Assumptions: Reconsidering nature}

Locke builds his logical foundation on a few basic assumptions about nature. Changing the assumptions that Locke makes about land and nature results in a different ideational structure.

Locke makes two key explicit assumptions and several implicit assumptions that are worth reconsidering. First, he assumes that land left unimproved is wasteland or land available for ownership and cultivation. Second, Locke insists that improved land is much more productive than unimproved land. These things he says explicitly. On the other hand, Locke implies that the increased abundance of developed land is invariably the rule. He assigns considerable weight to this increased abundance: it provides a justification for the unequal ownership of land and supports a way of life far beyond the subsistence level that would have been the case without harnessing the productive power of the land (Reno 2009).

Locke treats land, its products, and to a lesser degree, the "inferior creatures" as "provisions" yielded up by an ecosystem's "provisioning services," as defined in the Millennium Ecosystem Assessment (MEA) Synthesis report (2005). The concept of Ecological Goods and Services (EG\&S), however, establishes a more comprehensive understanding of the usefulness of natural systems and their elements to humankind. As defined by the MEA (2005: v), EG \& S are the many "benefits people obtain from ecosystems". These extend beyond "provisioning services" to "supporting services", or those natural processes such as nutrient cycling, soil formation and primary biological production, that are essential to produce those products in nature that we know. The MEA also identifies "regulating services" such as climate, flood and disease regulation and water purification, and "cultural services" such as the meaning nature provides to life through aesthetic, spiritual, educational and recreational experiences.

The MEA approach fits nicely with Locke because it too is highly anthropocentric: it is concerned with human well-being, and incorporates the "freedom of choice and action, including the opportunity to achieve what an individual values doing and being" (MEA 2005) as an essential component of wellbeing. But the MEA goes beyond Locke's understanding of the natural basis that underlies human-well-being. First, uncultivated land may not be "waste" at all but essential to regulating and supporting ecosystem services; and it may not be the case that all land under cultivation - or used for a parking lot or a building - should be so used. In other words, land and creatures are not simply products of nature, they must be understood and their use evaluated with respect to their role in natural systems. This means that damaging land (or other components of nature) might do more than simply directly deprive an individual (or his offspring) of the fruits of his land; it might cause wider damage that strikes at the ability of nature to generate material abundance more generally. Even if we grant to the individual the right to destroy her or his own property (noting the limitation with respect to preserving the 
inheritance of children), there can be no right to destroy the property of others either directly or indirectly - through the destruction of supporting and regulating services that are essential for the healthy property of others. Doing the latter would destroy the necessary abundance and mean a violation of the essential condition for the enclosure of land: that what remains be "enough and as good as" for posterity. In addition, a collective interest exists in preserving the natural systems that provide the precondition for an abundance that allows the construction of something more than a primitive society (as well as the continued existence of humans and other creatures).

In connection with this, note that the concept of ecosystem also carries with it the idea of something large and complicated, the boundaries of which usually do not correspond with individual property or even national boundaries. When this is the case, one can readily see how an entire ecosystem might be undermined by an action within one part of it that happens to be enclosed as private property. Locke does not presume that individuals have any right to commit such actions. Attempting to remedy this problem of harming the property of others or land still held in common by staking a claim to the entire ecosystem would have to fail, because such a level of control could not leave "enough and as good" for others.

To step outside of Locke, the concept of the ecosystem in itself implies that infinite growth with respect to the use of only one or a few aspects of it is not compatible with the continued function of that system in its original state. The concept of growth in this context can easily connote a lack of balance, representing danger rather than vitality. This puts real limits on what humans may do if we are to achieve Locke's fundamental assumption of the continued productivity of ecosystems (Trachtenberg makes a similar point. See 2014: 107).

Unlimited use and growth - and any other behavior that endangers fundamental ecosystem services - then imperil the well-being of others in ways that Locke might well understand and accept. For Locke, men do not give up the right to self-defense in nature or in political society. And Locke goes far in giving man the right not just to subsistence but also to a degree of comfort. If one is actively destroying the basis upon which others' existence and well-being - and even comfort - rest, this would give the injured party some right to take action against the individual causing the damage. Note that all use of land and all consumption have some impact on an ecosystem: this impact may be positive or negative, significant or trivial. The harm principle comes into play most clearly when the resilience of the ecosystem is at risk, but less egregious threats to the ecosystem may still have real impact on the EG\&S available to others.

This takes us back to Locke's fundamental understanding of the function of government. Men cannot be judges in their own interest. They are unlikely to perform this task well, given the even more complex calculations of harm that an ecosystem approach requires. Government, then, is instituted for precisely this reason: to discern the nature of harm being done, to settle upon guilt or innocence and to establish the remedy (Coase 1960; see also Haddad 2003). Locke tends to think here in terms of penalties against the guilty party. However, it is not difficult to derive from his work the right of a legislature to identify harmful societal practices or measures by which potential harm is to be prevented. As is the case in establishing the right of legislatures to tax, the majority or its representatives can establish this and make positive law. 
Returning to the points made about taxation, a foundation exists here for the idea that the government (especially the legislature) may establish which actions cause harm to others and how these actions may be dealt with. It is not necessary that every individual within a political society agree with every action of the legislature. The majority may take action with the goal of protecting the property rights of all, which is the reason for creating government in the first place. Locke provides a foundation to support the position that when a majority accepts that particular actions of individuals or an aggregation of individuals are causing harm to the basis of human life and comfort, those individuals should accept this judgment and the right of the legislature to limit their action. Instead of impinging upon individual rights and depriving the individual of income that a destructive act might generate over the short term, such an action by the majority to would constitute a binding interpretation as to what the harm principle - already accepted as a guiding principle of natural law - means in specific situations. The failure of government to perform this role can lead to precisely the situation that characterizes the state of nature, according to Locke: individuals taking action according to their own judgment and initiative.

\section{Conclusion}

Embedded in the writings of Locke are key values, concepts and assumptions that can be used to construct a compelling argument for limitations to human action and for the reinterpretation of the value accorded to "growth" in today's economic and political contexts, from the perspective of the damage these can have on natural systems. These values, concepts and assumptions become most powerful, however, when placed within an updated understanding of the structure and functioning of natural systems.

At first reading, Locke emphasizes the happiness of the individual and the protection of property (which is the precondition for this happiness) as the ends of political society and government. Humans' "unease" and desire to obtain more goods are insatiable, and the ability of the individual to pursue happiness through the pursuit and consumption of goods is synonymous with liberty. The lack of an objectively defined notion of good or an explicit recognition of a collective good beyond the sum of the happiness of individuals seems to leave little room for placing limits on the pursuit of ever greater consumption and use of the Earth's resources by the individual.

But embedded in Locke are the seeds of both limits on individual behavior and a limited recognition of a collective good, that is, a good that transcends a utilitarian calculation of the common good. Humans are social beings with the obligation to care for each other; parents have an inherent concern for their children and an obligation to preserve property for their offspring's use. Locke's embrace of the essential equality of all people is foundational, even as he finds a way to accept inequality in political society.

The clearest foundations in Locke for protecting the environment lie in his ideas that the Earth is given to humankind in common, in his version of the harm principle and even in his notion of private property. While there is much to suggest that a "possessive individualist" Locke gives the individual almost unlimited rights to dispose of his property as he pleases, it is clear that individuals do not have the 
right to damage the private property of others or the nature that is held in common. An ecosystem perspective helps us to see that much human behavior may potentially do just that. For that reason, the requirement to respect private property becomes a major reason to lessen stress on ecosystems. Not only are government and political society instituted to protect private property, but individuals never give up their right to self-defense, including defense of property on which their wellbeing depends.

There remains the problem of calculating the harm done to the property of others or to unclaimed land by individuals pursuing their private ends on their own land. What happens on one patch of land within an ecosystem can affect the whole ecosystem; it may either enhance or diminish the productive power of others' land or of the ecosystem in general. Such effects may be significant or trivial. This can open the door to endless arguments about what harm may have been done, and what the remedy should be. Dealing with issues such as these is precisely the role Locke envisions for government. In addition, government may move to carry out its responsibility even when not every individual in society is in agreement with proposed measures. By the same reasoning, protection of natural systems becomes a core value of liberalism, because this is required for the protection of private property, material abundance and accordingly, the promotion of human happiness.

\section{Acknowledgements}

The authors would like to thank Michael Lipscomb and two anonymous reviewers for their very helpful comments.

\section{Notes}

${ }^{1} \mathrm{I}=$ human impact, $\mathrm{P}=$ human population, $\mathrm{A}=$ affluence, $\mathrm{T}=$ technology. Cited in Paterson and others (2012: 31).

${ }^{2}$ The Stockholm Resilience Center (2015b) identifies these as: 1) the stratospheric ozone layer; 2) biodiversity; 3) chemicals dispersion; 4) climate; 5) ocean acidification; 6) freshwater consumption and the global hydrological cycle; 7) the land system (relating to land use); 8) nitrogen and phosphorus inputs to the biosphere and the oceans; and 9) atmospheric aerosol loading.

${ }^{3}$ Critics suggest that there is little sign of impending catastrophe and that previous forecasts of environmental catastrophe have been notoriously and spectacularly wrong. Thomas Robert Malthus, writing in 1798, famously argued that the productivity of the Earth had limits and that these limits in turn set boundaries for society (Malthus 1982 [1798]). The idea is far older than this: one author traces it back to Giovanni Botero in 1601 and it is likely older than this (Knutsen 2003). More recently, the Club of Rome in 1972 warned about "limits to growth" (Club of Rome 1972). That the predictions these sources made did not pan out is widely cited by skeptics in support of their dismissal of current predictions about climate change.

${ }^{4}$ The "survivalist" discourse, for example, describes the attitudes of those with the fixed idea that boundaries and limits exist and that these are being transgressed, while the "promethean" discourse describes the views of those who are supremely 
confident that humanity will invent a way out of any apparent problem (Dryzek 2005).

${ }^{5}$ The precautionary principle is for example found in the Montreal Protocol, the Rio Declaration (Principle 15), and the Kyoto Protocol (Article 3.3) and has been adopted by the European Union (Communication from the commission on the precautionary principle (European Union 2000)).

6 There is also a significant body of literature that supports the idea that the extension of private property rights is the best way to protect the environment and its resources. See Harden and his 1968 argument that individual behavior with respect to the "commons" would lead relentlessly to the destruction of the commons (see also Adler 2005 \& 2012). The idea of the importance of establishing property rights as an answer to overfishing is particularly popular today in fisheries management (see for example Costello, Gaines and Lynham 2008). This paper will not address the extensive debate on property rights and their effects on the environment.

${ }^{7}$ While there has been an historical debate as to just how important Locke was for the US "founding fathers", there is a widespread belief today that Locke's work was indeed formative for them. For an example of this common assumption, see the remarks that George W. Bush made at Whitehall Palace in London on 19 November 2003 (Bush 2003).

${ }^{8}$ Such as granting animals or the ecosystem rights independent of human rights. Granting rights becomes complicated for many reasons, one of which is the lack of reciprocal obligations that rights-holders have. See for example the discussion in Wissenburg (2005).

${ }^{9}$ Locke's Second Treatise on Government is abbreviated here " $2^{\text {nd }} T$ ", and rather than page, the location of the quotation or point is given as chapter and subsection, which will hold for any edition of these works. The First Treatise is designated " $1^{\text {st }}$ T", and Essay Concerning Human Understanding as "ECHU". Locations in these texts are given on the same principle used with respect to the Second Treatise.

10 The "enough and as good as" argument is a primary argument of the Liebell (2011) article from which this point comes.

${ }^{11}$ Otsuka (1998: 66) is in fact making this point with respect to Nozick, but the larger point applies to MacPherson.

$122^{\text {nd }}$ T., Ch. V, $₫ 26$. "The earth and all that is therein is given to men for the support and comfort of their being."

${ }^{13}$ This is a function of Locke's empirical-based notion of human understanding. Related to this he notes first that "happiness then in its full extent is the utmost pleasure we are capable of, and misery the utmost pain:[...] what has an aptness to produce pleasure in us is that which we call good, and what is apt to produce pain in us we call evil, for no other reason, but for its aptness to produce pleasure and pain in us, wherein consists our happiness and misery" (ECHU \$42).

${ }^{14}$ Locke says, for example, "As much land as man tills, plants, improves, cultivates, and can use the product of, so much is his property" ( $2^{\text {nd }} T$. Ch. V $\left.\$ 32\right)$, which seems to establish that "improved" land itself is owned.

${ }^{15}$ In $2^{\text {nd }} \mathrm{T}$, Ch. VII, $\$ 77$, Locke writes: “God having made man such a creature, that in his own judgment, it was not good for him to be alone, put him under strong obligations of necessity, convenience, and inclination to drive him into society, as well as fitted him with understanding and language to continue and enjoy it." 
${ }^{16}$ This extract is from this passage: "That it is not at all to be wondered, that history gives us but a very little account of men, that lived together in the state of nature. The inconveniences of that condition, and the love and want of society, no sooner brought any number of them together, but they presently united and incorporated, if they designated to continue together."

17 See for example the Evangelical Environmental Network (EEN), which is "grounded in the Bible's teaching on the responsibility of God's people to 'tend the garden' through a faithful walk with our Lord Jesus Christ” (EEN 2015).

\section{References}

Adler, J. H., (2012, May 29). How property rights could help save the environment. The Atlantic: Business online. Retrieved July, 29, 2015, from http://www.theatlantic.com/business/archive/2012/05/how-property-rightscould-help-save-the-environment/257756/

Adler, J. H. (2005). Back to the future of conservation: Changing perceptions of property rights \& environmental protection. NYU journal of law and liberty 1(3): 987-1033. Retrieved from http://papers.ssrn.com/sol3/papers.cfm? abstract_id $=759653$

Breakey, H. (2014). Parsing Macpherson: The last rites of Locke the possessive individualist. Theoria 80: 62-83. https://dx.doi.org/10.1111/theo.12022

Bush, G. W. (2003, November 19). Remarks at Whitehall Palace in London, United Kingdom, in Woolley, J. and Peters, G. The American presidency project. Retrieved August 1, 2015, from http://www.presidency.ucsb.edu/ws/ index.php?pid=812\&st=John+Locke\&st $1=\#$ ixzz1 VmDpUlFV

Clark, I. D., and others. (2006, 11 April). Open Kyoto to debate: Sixty scientists call on Harper to revisit the science of global warming. National post. Retrieved August, 17, 2016, from http://www.epw.senate.gov/public/index.cfm/in-thenews?ID=1E639422-7094-4972-83AF-EE40EE302D41

Coase, R. (1960). The problem of social cost. Journal of law and economics 3(1): 144. https://doi.org/10.1086/466560

Club of Rome (1972). Limits to growth. New York, Universe Books.

Costello, C., Gaines, S.D., and Lynham, J. (2008). Can catch shares prevent fisheries collapse? Science 321(5896): 1678-1681. http://dx.doi.org/10.1126/ science. 1159478

Cullet, P. (1995). Definition of an environmental right in a human rights context. International Environmental Law Research Centre. Netherlands Quarterly of Human Rights 13(1): 25-40. Retrieved August 17, 2016, from http://www.ielrc.org/content/a9502.pdf

Dryzek, J. S. (2005). The Politics of the Earth: Environmental discourses. 2nd ed. Oxford, Oxford University Press.

Dunn, J. (1969). The Political Thought of John Locke. Cambridge, Cambridge University Press. https://doi.org/10.1017/cbo9780511558436

EEN (2015). Evangelical Environmental Network. Creation care. It's a matter of life. Retrieved March 20, 2015, from http://www.creationcare.org/

European Union (2000). Communication from the Commission on the precautionary principle. EUR-Lex. Retrieved March, 15 2015, from http://eurlex.europa.eu/legal-content/EN/TXT/?uri=celex:52000DC0001 
Goldwin, R. A. 1976. Locke's state of nature in political society. Western political quarterly 29(1): 126-135. http://dx.doi.org/10.1177/106591297602900109

Haddad, B. M. (2003). Property rights, ecosystem management, and John Locke's labor theory of ownership. Ecological economics 46(1), 19-31. http://dx.doi.org/10.1016/S0921-8009(03)00079-X

Hardin, G. (1968). The Tragedy of the Commons. Science, New Series 162(3859): 1243-1248. Stable URL: http://www.jstor.org/stable/1724745

Hartz, L. (1955). The Liberal tradition in America. New York and London, Harcourt Brace Jovanovich.

Heywood, A. (2012). Political ideologies: An introduction. 5th ed. Hampshire, Palgrave Macmillan.

Hindess, B. (2007). Locke's state of nature. History of the human sciences 20(3): 1-20. http://doi.org/10.1177/0952695107079331

Inhofe, J. M. (2006). Hot \& cold media spin cycle: A challenge to journalists who cover global warming. A skeptic's guide to debunking global warming alarmism. In Inhofe, J.M. Senate floor speech delivered Monday September 25, 2006 and global warming related material. Retrieved $15^{\text {th }}$ March 2015, from http://www.epw.senate.gov/speechitem.cfm?party=rep\&id=263759

Ince, O. U. (2011). Enclosing in God's name, accumulating for mankind: Money, morality and accumulation in John Locke's Theory of Property. The review of politics 73(1): 29-54. http://dx.doi.org/10.1017/S0034670510000859

IPCC (2014). Climate Change 2014: Synthesis Report. Contribution of Working Groups I, II and III to the Fifth Assessment Report of the Intergovernmental Panel on Climate Change [Core Writing Team, R.K. Pachauri and L.A. Meyer (eds.)]. IPCC, Geneva, Switzerland, 151 pp. Retrieved August 17, 2016, from https://www.ipcc.ch/pdf/assessment-report/ar5/syr/SYR_AR5_FINAL_full_ wcover.pdf

Jacques, P. J. (2009). Environmental skepticism: Ecology, power and public life. Farnham, England and Burlington, Vermont, Ashgate Publishing Group.

Karunanithi, A. T., Cabezas, H., Frieden, R, and Pawlowski, C. (2008). Detection and assessment of ecosystem regime shifts from fisher information. Ecology and society 13(1): 22. Retrieved August 17, 2016, from http://www.ecologyandsociety.org/vol13/iss1/art22/

Kendall, W. John Locke and the doctrine of majority rule. Urbana, University of Illinois Press.

Knutsen, T. L. (2003). Why is Malthus' essay a classic? In Jensen, A.-M., Knutsen, T.L. and Skonjoft, A. (Eds.), Visiting Malthus: The man, his times, the issue (pp. 21-43). Oslo, Abstrakt Forlag AS.

Liebell, S. P. (2011). The text and context of 'Enough and as Good': John Locke as the foundation of an environmental liberalism. Polity 43(2): 210-241. http://dx.doi.org/10.1057/pol.2010.28

Locke, J. (2007 [1689]). An essay concerning human understanding. Book II: Ideas. Published electronically and edited by J. Bennett. Retrieved March 15, 2015 from http://www.earlymoderntexts.com/authors/ locke

Locke, J. 2014 [1690]. Second treatise of government. Project Gutenberg EBook. Retrieved March 15, 2015 from http://www.gutenberg.org/files/7370/7370h/7370-h.htm 
Locke, J. 1824/2015 [1691]. First treatise of government: Of Government: Book 2. Retrieved $15^{\text {th }}$ March 2015, from http://www.nlnrac.org/earlymodern/locke/ documents/first-treatise-of-government

Lomborg, B. (2001). The skeptical environmentalist. Cambridge, Cambridge University Press. https://doi.org/10.1017/cbo9781139626378

Macpherson, C. B. (1973). Democratic theory: Essays in retrieval. Oxford, Clarendon Press.

Macpherson, C. B. (1962). The political theory of possessive individualism: Hobbes to Locke. London, Oxford University Press.

Malthus, R. T. (1982 [1798]). Essay on the principle of population as it affects the future improvement of society with remarks on the speculations of Mr. Godwin, $M$. Condorcet, and other writers. Harmondsworth, Penguin.

MEA (Millennium Ecosystem Assessment) (2005). Ecosystems and human wellbeing: General Synthesis. Washington, D.C., Island Press. Retrieved August 17, 2016, from http://millenniumassessment.org/en/Synthesis.html

Miller, D. (1980). Hume and possessive individualism. History of political thought 1(2): 261-78.

Meyer, J. M. (2009). The concept of private property and the limits of the environmental imagination. Political theory 37(1): 99-127. http://dx.doi.org/ $10.1177 / 0090591708326644$

NASA (2015). Scientific consensus: Earth's climate is warming. Retrieved December 14, 2015 from http://climate.nasa.gov/scientific-consensus/

Nozick, R. (1974). Anarchy, state and utopia, New York, Basic Books.

NOAA. (2006). Bering climate: Regime shift detection. Online. Retrieved July 27, 2015, from http://www.beringclimate.noaa.gov/regimes/

Otsuka, M. (1998). Self-ownership and equality: A Lockean reconciliation. Philosophy \& public affairs 27(1): 65-92. https://doi.org/10.1111/j.10884963.1998.tb00061.x

Paterson, D. M., Defew, E.C. and Jabour J. (2012). Ecosystem function and coevolution of terminology in marine science and management. In Solan, M., Aspden R.J. and Paterson, D.M. (Eds.), Marine bioldiversity and ecosystem functioning: Frameworks, methodologies, and integration (pp. 25-33). Oxford, Oxford University Press. https://doi.org/10.1093/acprof:oso/ 9780199642250. 003.0003

Pellow, D. N. (1999). Framing emerging environmental movement tactics: Mobilizing consensus, demobilizing conflict. Sociological forum 14(4): 659683. Stable URL: http://www.jstor.org/stable/685078

Reno, J. B. (2009). Private property and the law of nature in Locke's two treatises: The best advantage of life and convenience. American journal of economics and sociology 68 (3): 639-64. https://doi.org/10.1111/j.1536-7150.2009.00645.x

Rockström, J., Steffen, W., Noone, K., Persson III, Å., Chapin, F. S., Lambin, E., .. . Foley J. (2009). Planetary boundaries: Exploring the safe operating space for humanity. Ecology and society 14(2): Art. 32. Retrieved August 17, 2016, from http://www.ecologyandsociety.org/vol14/iss2/art32/

Schneewind, J. B. (1994). Locke's moral philosophy. In Chappell, V. (Ed.), The Cambridge companion to Locke (pp. 199-225). Cambridge, Cambridge University Press. https://doi.org/10.1017/ccol0521383714.009 
Shani, A. and Arad, B. (2014). Climate change and tourism: Time for environmental skepticism. Tourism management 44: 82-5. http://dx.doi.org/ 10.1016/j.tourman.2014.02.014

Sigmund, P. E. (2005). Jeremy Waldron and the religious turn in Locke scholarship. Review of politics 67(3): 407-418. http://dx.doi.org/10.1017/S00346705000 3463X

Simmons, J. (1993). On the edge of anarchy: Property, consent and the limits of society. Princeton, Princeton University Press.

Stockholm Resilience Center. (2015a). Regime shifts and their implications in social-ecological systems. Retrieved August 17, 2016, from http://www.stockholmresilience.org/research/research-themes/regimeshifts.html

Stockholm Resilience Center. (2015b). The nine planetary boundaries. Retrieved August 17, 2016, from http://www.stockholmresilience.org/research/ planetary-boundaries/planetary-boundaries/about-the-research/the-nineplanetary-boundaries.html

Snow, D. A, Rochford, Jr., E.B., Worden, S.K. and Bendor R.D. (1986). Frame alignment processes, micromobilization, and movement participation. American sociological review 51(4): 464-481. http://dx.doi.org/10.2307/ 2095581

Williams, R. H. (2004). The cultural context of collective action: Constraints, opportunities, and the symbolic life of social movements. In Snow, D. A., Soule S. A. and Kriesi, H. (Eds.), The Blackwell companion to social movements (pp. 91-115). Malden, MA, Blackwell Publishing Ltd. https://doi.org/10.1002/9780470999103.ch5

Trachtenberg, Z. (2014). This habitable Earth of ours. In Cannavò P.F. and Lane, J. H., (Eds)., Engaging nature (pp. 99-116), Cambridge, MA, MIT Press.

Varden, H. (2012). The Lockean 'enough-and-as-good' proviso: An internal critique. Journal of moral philosophy 9:410-442. http://dx.doi.org/10.1163/ 174552412 X625772

Vaughn, K. (1980). John Locke's theory of property: Problems of interpretation. Literature of liberty: A review of contemporary liberal thought 3(1): 5-37. Retrieved August 17, 2016, from http://oll.libertyfund.org/titles/liggioliterature-of-liberty-spring-1980-vol-3-no-1

Waldron, J. (1979). Enough and as good left for others. The philosophical quarterly 29 (117): 319-328. http://dx.doi.org/10.2307/2219447

Waldron, J. (2002). God, Locke, and equality: Christian foundations in Locke's political thought. West Nyack, New York, Cambridge University Press.

Weisenthal, J. (2009, July 30). The 10 most-respected global warming skeptics. Business insider "Green sheet". Retrieved March 20, 2015, from: http://www.businessinsider.com/the-ten-most-important-climate-changeskeptics-2009-7/freeman-dyson-1?IR=T

Wissenburg, M. L. J. (2005). Sustainability and the limits of liberalism. In Dryzek, J. S. and Schlosberg, D. (Eds), Debating the Earth: The environmental politics reader (pp. 180-190). $2^{\text {nd }}$ edition, Oxford, Oxford University Press.

Wills, G. (1999). A necessary evil. New York, Simon \& Schuster. 